\title{
Influence of Densification Temperafure on Some Physical and Mechanical Properties of Pferocarya Fraxinifolia Wood
}

\section{Utjecaj temperature pri ugušćivanju drva Pterocarya fraxinifolia na njegova fizikalna i mehanička svojstva}

Preliminary paper • Prethodno priopćenje

Received-prispjelo: 30. 8. 2017.

Accepted-prihvaćeno: 13. 6. 2018.

UDK: $630 * 812.463 ; 630 * 812.7$

doi:10.5552/drind.2018.1750

\begin{abstract}
This study has been conducted to investigate the influence of temperature levels in the densification process by hot-press methods on the physical and mechanical properties of false walnut wood (Pterocarya fraxinifolia). For this purpose, wood specimens from five standing trees were compressed at different densification temperatures $\left(110,140\right.$ and $\left.170^{\circ} \mathrm{C}\right)$. Then, the data of oven dry density, modulus of rupture, modulus of elasticity in bending and withdrawal strength of nail of compressed wood were analyzed by SPSS software. Analysis of variance (ANOVA) indicated that the densification temperature had significant effects on the physical and mechanical properties. The most suitable temperature level was $140{ }^{\circ} \mathrm{C}$ for a higher density, modulus of rupture, modulus of elasticity in bending, and withdrawal strength of nail in the densification of false walnut wood. Increase of $27 \%$ in the density, $80 \%$ in the modulus of elasticity (MOE), $252 \%$ in the modulus of rupture (MOR) and $215 \%$ in the withdrawal strength of nail were obtained after densification.
\end{abstract}

Keywords: false walnut wood, densification temperature, physical properties, mechanical properties

SAŽETAK • Studija je provedena kako bi se istražio utjecaj temperature na fizikalna i mehanička svojstva drva „, lažnog “ oraha (Pterocarya fraxinifolia) u procesu njegova ugušćivanja metodom toplog prešanja. Za tu namjenu izrađeni su drvni uzorci od pet stabala te su podvrgnuti procesu ugušćivanja pri različitim temperaturama (110, $140 \mathrm{i} 170^{\circ} \mathrm{C}$ ). Nakon toga određena je i analizirana gustoća drva u apsolutno suhom stanju, modul loma, modul elastičnosti pri savijanju i čvrstoća držanja čavala ugušćenog drva. Analiza varijance (ANOVA) pokazala je da temperatura procesa ugušćivanja ima znatan utjecaj na fizikalna i mehanička svojstva drva. Najboljom temperaturom procesa povećanja gustoće drva, modula loma, modula elastičnosti pri savijanju i čvrstoće držanja čavala ugušćenog drva ,,lažnog “ oraha pokazala se ona od $140{ }^{\circ} \mathrm{C}$. Nakon ugušćivanja zabilježeno je povećanje gustoće drva od $27 \%$, modula elastičnosti od $80 \%$, modula loma od $252 \%$ i čvrstoće držanja čavala od $215 \%$.

Ključne riječi: ,,lažno“ drvo oraha, temperatura ugušćivanja, fizikalna svojstva drva, mehanička svojstva drva

\footnotetext{
${ }^{1}$ Authors are associate professor and associate professorat Department of Wood and Paper Science and Technology, Chalous Branch, Islamic Azad University, Chalous, Iran. ${ }^{2}$ Author is young Ph.D. student at Young Researcher and Elites Club, Chalous Branch, Islamic Azad University, Chalous, Iran.

${ }^{1}$ Autori su izvanredni profesori Odjela za znanost i tehnologiju drva i papira, Chalous Branch, Islamsko sveučilište Azad, Chalous, Iran. ${ }^{2}$ Autor je Ph.D. student Young Researcher and Elites Club, Chalous Branch, Islamsko sveučilište Azad, Chalous, Iran.
} 


\section{INTRODUCTION}

\section{UVOD}

False walnut wood (Pterocarya fraxinifolia) is a species of Jouglandaceae family. The height of these trees reaches $35 \mathrm{~m}$ and diameter at breast height 130 $\mathrm{cm}$. This species grows in northern Iran from Astara (Guilan province) to Minoodashat (Golestan province). It grows in mixed stands with alder, maple, hornbeam, ash, etc. Approximately $0.33 \%$ of northern forests in Iran are covered with false walnut wood. It is a species of wood with low density (Ebrahimi et al., 2004). Thermo-mechanical modification is a technique of wood densification that combines heat treatment with mechanical compression. In the mentioned modification, densification occurs with buckling of cell walls, which reduces pore-volume (Kutnar et al., 2009; Candan et al., 2013). In order to ensure suitable properties of the modified wood, modification should occur at an ideal temperature, in which the amorphous polymers of wood (lignin and hemicelluloses) pass from the glassy state to the rubbery state (Akerholm and Salmén, 2004). It is defined as the glass transition temperature $(\mathrm{Tg})$ and it varies with species and moisture content used. To this point, wood can be compressed without collapse in the cell wall structure (Sözbir and Bektas, 2017; Esteves et al., 2017; Tu et al., 2014).

There are widespread reports on wood densification. Madhoushi et al. (2012) indicated that the percentage of densification significantly influence the density of poplar wood, especially at higher compression percentages $(50 \%)$. Also, the amount of densification has significant influence on the withdrawal strength of nails (up to $220 \%$ ) and screws (up to $120 \%$ ). Compared with control specimens, MOR and $M O E$ were increased by $70 \%$ and $40 \%$, respectively.

Edalat et al. (2008) investigated the densification of paulownia wood by hot-press method. They indicated significant influence of densification temperature and compression percentage on the mechanical properties. The highest mechanical properties of wood specimens were found in $50 \%$ compression.

Ulcer et al. (2012) reported that the increase in densification temperature decreased strength properties of Scots pine wood. The most suitable densification temperature for increasing bending, shear and compression strength was $120^{\circ} \mathrm{C}$, and $140{ }^{\circ} \mathrm{C}$ for increasing radial and tangential hardness. Alen et al. (2009) stated that, at temperatures above $100{ }^{\circ} \mathrm{C}$, the intermolecular and intramolecular chemical bonds begin to break with a rate that would intensify as the heating time increases. This phenomenon could be due to thermal softening and loss of amorphous polysaccharides, which are responsible for a tight combination of cellulosic fibers and amorphous matrix including lignin. Bond breakage can also be attributed to the possibility of lignin relocation. Jiang et al. (2009) reported that treatment at $160{ }^{\circ} \mathrm{C}$ is probably enough to cause lignin molecules, which are located between the fibril aggregates, to change their position and damage the adhesive linkage of lignin with cellulose fibrils.
According to relative investigations, the densification temperature level is one of the most important factors in wood densification. This study aims to enhance thermo-mechanically the density of false walnut wood by pressing it in a stable pressure and heat at different temperatures. The main objective of this research was to determine the impact of densification temperature on the physical and mechanical properties of false walnut wood.

\section{MATERIALS AND METHODS 2. MATERIJALI I METODE}

For the present study, 5 logs of Pterocarya fraxinifolia tree were cut from Sari forests. Then specimens were made to determine their density and moisture content. Densification temperature was the variable factor of the present study and it was tested at three different levels of 110,140 and $170{ }^{\circ} \mathrm{C}$ with 6 repetitions. To have similar sample dimensions for mechanical properties, length and width $(400 \times 80$ $\mathrm{mm}$ ) of all samples were considered equal. However, the thickness of specimens corresponded to compression percentage in order to reach $20 \mathrm{~mm}$ thickness for all samples after compression. Therefore, according to $30 \%$ compression, the primary thickness of samples was considered as $28.5 \mathrm{~mm}$. The thickness of control samples was considered as $20 \mathrm{~mm}$. The prepared samples were from sapwood and tangential section. The thickness of all samples was measured after cutting and it was recorded as $T_{0}$. After that, the samples with primary moisture of $15 \%$ were put into a laboratory oven at the temperature of $50{ }^{\circ} \mathrm{C}$ for $72 \mathrm{~h}$ to decrease their moisture to $5 \%$ and prepare them for pressing.

Heating was done so that the hot surface of the press made contact with sample surfaces without compressing the wood. All samples were heated for $5 \mathrm{~min}$ utes. After final heating, all samples were exposed to the final pressure of $40 \mathrm{~kg} / \mathrm{cm}^{2}$, which was applied on wood surfaces to complete the compression process. The final thicknesses were controlled by $20 \mathrm{~mm}$ steel plates. The keeping time for final thickness was 4 minutes in all treatments. After sample compression and after opening the press surfaces, the samples were transferred to the oven and kept at $50{ }^{\circ} \mathrm{C}$ to prevent the creation of disadvantages resulting from rapid reduction of densification temperature. After one hour the thickness of samples was measured and it was recorded as $T_{1}$. All samples were kept at $21^{\circ} \mathrm{C}$ and relative moisture of $65 \%$ for 3 weeks and their thickness was measured again and it was recorded as $T_{2}$.

\subsection{Oven dry density}

2.1. Gustoća u apsolutno suhom stanju

The density was determined in accordance with ISO $3131(25 \times 20 \times 20 \mathrm{~mm})$. This property is defined as the ratio of weight and volume of the specimen in the oven dry state. The number of specimens for oven dry density was 24 ( 18 specimens for densified wood and 6 specimens for control). 


\subsection{MOR and MOE}

2.2. Modul loma $(M O R)$ i modul elastičnosti $(M O E)$

Modulus of rupture (MOR) and modulus of elasticity $(M O E)$ were determined according to ISO 3133 standard $(370 \times 20 \times 20 \mathrm{~mm})$. Specimens were conditioned at temperature of $20^{\circ} \mathrm{C}$ and $65 \pm 5 \%$ relative humidity until they reached equilibrium moisture content of about $12 \%$. The load was applied in the tangential direction. Bending of specimens was applied on Instron (model 4486). 24 specimens were examined for each mechanical property (18 specimens for densified wood and 6 specimens for control).

\subsection{Withdrawal strength of nail}

\section{3. Čvrstoća držanja čavala}

Examination of withdrawal strength of nail was carried out with a mechanical test system connected to a computer equipped with strength data analysis software. Length and Penetration depth of nails were 30 and $1.6 \mathrm{~mm}$, respectively, according to the BS EN 1383-1999 $(50 \times 50 \times 20 \mathrm{~mm})$ standards. This property was calculated by dividing the maximum force $(\mathrm{N})$ and the nail penetration length (mm).

\subsection{Statistical analysis}

2.4. Statistička analiza

In this study, the influence of densification temperature on oven dry density, modulus of rupture
$(M O R)$, modulus of elasticity (MOE) and withdrawal strength of nail on densification of false walnut wood were analyzed by analysis of variance (ANOVA) and SPSS statistical software (IBM SOFTWARE, Armonk, New York, version 21), and a Duncan multi domain test was conducted to compare the means at a $95 \%$ confidence level.

\section{RESULTS AND DISCUSSION 3. REZULTATI I RASPRAVA}

Descriptive statistical analysis of oven dry density and mechanical properties of densified false walnut wood are given in Table 1 . The analysis of variance (ANOVA) related to whether or not the temperature level applied in densification was effective relative to the oven dry density, modulus of elasticity, modulus of rupture and withdrawal strength of nail is given in Table 2. Table 2 shows that temperature level affected all the investigated properties $(p<0.05)$. Table 3 shows the homogeneity test results related to the temperature levels that created a difference according to the values of oven dry density, MOE, MOR and withdrawal strength of nail.

After the process of densification, oven dry density of false walnut increased from $445 \mathrm{~kg} / \mathrm{m}^{3}$ to 564 $\mathrm{kg} / \mathrm{m}^{3}$ at all temperature levels, and a $27 \%$ increase in density was achieved. Since the control specimens and

Table 1 Descriptive statistical analysis of density and mechanical properties of densified false walnut wood

Tablica 1. Deskriptivna statistička analiza gustoće i mehaničkih svojstava ugušćenog drva „lažnog“ oraha

\begin{tabular}{|c|c|c|c|c|}
\hline \multicolumn{2}{|l|}{ Wood properties / Svojstva drva } & \multirow{2}{*}{$\begin{array}{c}\text { Mean } \\
\text { Srednja vrijednost } \\
445\end{array}$} & \multirow{2}{*}{$\begin{array}{c}\text { Standard deviation } \\
\text { Standardna devijacija } \\
39\end{array}$} & \multirow{2}{*}{$\begin{array}{c}\text { Variation coefficient } \\
\text { Koeficijent varijacije } \\
\%\end{array}$} \\
\hline \multirow{4}{*}{$\begin{array}{l}\text { Oven dry density, } \mathrm{g} / \mathrm{m}^{3} \\
\text { gustoća u apsolutno suhom stanju, } \mathrm{g} / \mathrm{m}^{3}\end{array}$} & Control & & & \\
\hline & 110 & 532 & 11 & 2.06 \\
\hline & 140 & 564 & 28 & 4.96 \\
\hline & 170 & 519 & 36 & 6.93 \\
\hline \multirow{4}{*}{$\begin{array}{l}\text { Modulus of elasticity, } \mathrm{N} / \mathrm{mm}^{2} \\
\text { modul elastičnosti, } \mathrm{N} / \mathrm{mm}^{2}\end{array}$} & Control & 3195.49 & 131.21 & 4.11 \\
\hline & 110 & 5359.30 & 140.15 & 2.62 \\
\hline & 140 & 5740.74 & 548.82 & 9.56 \\
\hline & 170 & 5245.62 & 208.77 & 3.98 \\
\hline \multirow{4}{*}{$\begin{array}{l}\text { Modulus of rupture, } \mathrm{N} / \mathrm{mm}^{2} \\
\text { modul loma }, \mathrm{N} / \mathrm{mm}^{2}\end{array}$} & Control & 21.17 & 3.21 & 15.16 \\
\hline & 110 & 59.47 & 8.07 & 13.57 \\
\hline & 140 & 74.55 & 9.45 & 12.67 \\
\hline & 170 & 54.42 & 1.88 & 3.45 \\
\hline \multirow{4}{*}{$\begin{array}{l}\text { Withdrawal strength of nail, } \mathrm{N} / \mathrm{mm} \\
\text { čvrstoća držanja čavala, } \mathrm{N} / \mathrm{mm}\end{array}$} & Control & 7.80 & 1.66 & 21.28 \\
\hline & 110 & 15.86 & 2.39 & 15.06 \\
\hline & 140 & 24.52 & 4.72 & 19.24 \\
\hline & 170 & 13.80 & 2.49 & 18.04 \\
\hline
\end{tabular}

Table 2 Analysis of variance (ANOVA) related to the effect of temperature level on some physical and mechanical properties of densified wood

Tablica 2. Analiza varijance (ANOVA) vezana za utjecaj temperature na određena fizikalna i mehanička svojstva ugušćenog drva

\begin{tabular}{|l|c|c|c|}
\hline \multicolumn{1}{|c|}{$\begin{array}{c}\text { Variables } \\
\text { Svojstva }\end{array}$} & $\boldsymbol{F}$ & $\begin{array}{c}\text { p-value } \\
\text { p-vrijednost }\end{array}$ & $\begin{array}{c}\text { Significant } \\
\text { Značajno } \\
(p<0.05)\end{array}$ \\
\hline Oven dry density, $\mathrm{g} / \mathrm{m}^{3} /$ gustoća u apsolutno suhom stanju, $\mathrm{g} / \mathrm{m}^{3}$ & 10.689 & 0.001 & $\times$ \\
\hline Modulus of elasticity, $\mathrm{N} / \mathrm{mm}^{2} /$ modul elastičnosti, $\mathrm{N} / \mathrm{mm}^{2}$ & 55.084 & 0.001 & $\times$ \\
\hline Modulus of rupture, $\mathrm{N} / \mathrm{mm}^{2} /$ modul loma, $\mathrm{N} / \mathrm{mm}^{2}$ & 41.184 & 0.001 & $\times$ \\
\hline Withdrawal strength of nail, $\mathrm{N} / \mathrm{mm} /$ čvrstoća držanja čavala, $\mathrm{N} / \mathrm{mm}$ & 9.798 & 0.002 & $\times$ \\
\hline
\end{tabular}


Table 3 Homogeneity tests related to the determination of temperature levels that create a difference based on the values of oven dry density, MOE, MOR and withdrawal strength of nail

Tablica 3. Testovi homogenosti vezani za određivanje temperature procesa ugušćivanja drva koja utječe na razliku gustoće u apsolutno suhom stanju, na modul elastičnosti, modul loma i čvrstoću držanja čavala

\begin{tabular}{|c|c|c|c|c|c|}
\hline \multirow{2}{*}{$\begin{array}{l}\text { Variables } \\
\text { Svojstva }\end{array}$} & \multirow{2}{*}{$\begin{array}{c}\text { Densification temperature } \\
\text { Temperatura uguśćivanja } \\
{ }^{\circ} \mathrm{C}\end{array}$} & \multirow{2}{*}{$\begin{array}{c}\text { Number of specimens } \\
\text { Broj uzoraka }\end{array}$} & \multicolumn{3}{|c|}{$\begin{array}{l}\text { Homogeneity group } \\
\text { Grupa homogenosti }\end{array}$} \\
\hline & & & A & B & $\mathrm{C}$ \\
\hline \multirow{4}{*}{$\begin{array}{l}\text { Oven dry density, } \mathrm{g} / \mathrm{m}^{3} \\
\text { gustoća u apsolutno suhom stanju, } \\
\mathrm{g} / \mathrm{m}^{3}\end{array}$} & Control & 6 & 445 & & \\
\hline & 170 & 6 & & 519 & \\
\hline & 110 & 6 & & 532 & \\
\hline & 140 & 6 & & 564 & \\
\hline \multirow{4}{*}{$\begin{array}{l}\text { Modulus of elasticity, } \mathrm{N} / \mathrm{mm}^{2} \\
\text { modul elastičnosti, } \mathrm{N} / \mathrm{mm}^{2}\end{array}$} & Control & 6 & 3195.49 & & \\
\hline & 170 & 6 & & 5245.62 & \\
\hline & 110 & 6 & & 5359.30 & \\
\hline & 140 & 6 & & & 5740.74 \\
\hline \multirow{4}{*}{$\begin{array}{l}\text { Modulus of rupture, } \mathrm{N} / \mathrm{mm}^{2} \\
\text { modul loma, } \mathrm{N} / \mathrm{mm}^{2}\end{array}$} & Control & 6 & 21.17 & & \\
\hline & 170 & 6 & & 54.42 & \\
\hline & 110 & 6 & & 59.47 & \\
\hline & 140 & 6 & & & 74.55 \\
\hline \multirow{4}{*}{$\begin{array}{l}\text { Withdrawal strength of nail, N/mm } \\
\text { čvrstoća držanja čavala, N/mm }\end{array}$} & Control & 6 & 7.80 & & \\
\hline & 170 & 6 & 13.80 & 13.80 & \\
\hline & 110 & 6 & & 15.86 & \\
\hline & 140 & 6 & & & 24.52 \\
\hline
\end{tabular}

densified specimens appeared in separate homogeneity groups, the densification process was judged to be significantly affected by oven dry density. There are no significant differences among density values of the densified specimens heated to 110,140 and $170{ }^{\circ} \mathrm{C}$.

After the process of densification, $M O E$ of false walnut increased from 3195 to $5740 \mathrm{~N} / \mathrm{mm}^{2}$ at all temperature levels, and $80 \%$ increase in $M O E$ was achieved. Control specimens and densified specimens appeared in separate homogeneity groups according to Duncan's tables. There are no significant differences among the $M O E$ values of the densified specimens heated to 110,140 and $170{ }^{\circ} \mathrm{C}$. The differences in the $M O E$ between densified specimens at the temperature of 110 and $170{ }^{\circ} \mathrm{C}$ was not significant. The differences in the $M O E$ between densified specimens at the temperature of 110 and $140{ }^{\circ} \mathrm{C}$, and the modulus of elasticity $(M O E)$ of the densified specimens at 140 and 170 ${ }^{\circ} \mathrm{C}$ were significant.

Since the lowest MOR $\left(21.17 \mathrm{~N} / \mathrm{mm}^{2}\right)$ was obtained in the control specimens of false walnut wood, the densification process increased MOR. The highest mean value of $M O R$ was found in densified specimens at the temperature of $140{ }^{\circ} \mathrm{C}\left(74.55 \mathrm{~N} / \mathrm{mm}^{2}\right)$. The differences in the $M O R$ between densified specimens at the temperature of 110 and $170{ }^{\circ} \mathrm{C}$ was not significant. The differences in the $M O R$ between densified specimens at the temperature of 110 and $140{ }^{\circ} \mathrm{C}$, and the modulus of rupture (MOR) of the densified specimens at 140 and $170{ }^{\circ} \mathrm{C}$ were significant.

After the densification process, the withdrawal strength of nail of false walnut wood increased from 7.80 to $24.52 \mathrm{~N} / \mathrm{mm}$ at all temperature levels, and a 215 $\%$ increase in withdrawal strength of nail was achieved. Since the lowest withdrawal strength of nail $(7.80 \mathrm{~N} /$ $\mathrm{mm}$ ) was obtained in the control specimens, densification process increased the withdrawal strength of nail.
The highest mean value of withdrawal strength of nail was found in densified specimens at the temperature of $140{ }^{\circ} \mathrm{C}(24.52 \mathrm{~N} / \mathrm{mm})$. Control specimens and densified specimens at the temperature of $110^{\circ} \mathrm{C}$ and $140{ }^{\circ} \mathrm{C}$ appeared in separate homogeneity groups according to Duncan's tables.

The increase of temperature in the densification process affected all the strength properties of false walnut wood. The increase of the densification temperature level from $110{ }^{\circ} \mathrm{C}$ to $140^{\circ} \mathrm{C}$ in the false walnut wood affected the MOE (5359.30 and $5740.74 \mathrm{~N} /$ $\mathrm{mm}^{2}$ ), MOR (59.47 and $74.55 \mathrm{~N} / \mathrm{mm}^{2}$ ) and withdrawal strength of nail $\left(15.86\right.$ and $\left.24.52 \mathrm{~N} / \mathrm{mm}^{2}\right)$. The raising of the densification temperature to $170{ }^{\circ} \mathrm{C}$ decreased the MOE value to $5245.62 \mathrm{~N} / \mathrm{mm}^{2}$, the $M O R$ value to $54.42 \mathrm{~N} / \mathrm{mm}^{2}$ and withdrawal strength of nail value to $13.80 \mathrm{~N} / \mathrm{mm}$. The reason for the reduction of mechanical strength at $170{ }^{\circ} \mathrm{C}$ can be the change in chemical properties, change of wood cell wall, and the increase of intercellular space (Ülker et al., 2012; Jiang et al., 2009; Alen et al., 2002).

\section{CONCLUSIONS \\ 4. ZAKLJUČAK}

The main conclusions of this study are summarized below:

1. Densification process at temperatures of $110^{\circ} \mathrm{C}, 140$ ${ }^{\circ} \mathrm{C}$ and $170{ }^{\circ} \mathrm{C}$ affected the investigated physical and mechanical properties of false walnut wood.

2. By increasing the densification temperature to 140 ${ }^{\circ} \mathrm{C}$, oven dry density and mechanical properties increased, but there was a reduction when the densification temperature increased to $170{ }^{\circ} \mathrm{C}$.

3. The most suitable temperature level for densification of false walnut wood is $140{ }^{\circ} \mathrm{C}$ considering higher oven dry density, MOR, MOE, and withdrawal 
strength of nail. The oven dry density and mechanical properties of densified samples were improved compared to control specimens in false walnut wood

\section{REFERENCES}

\section{LITERATURA}

1. Akerholm, M.; Salmen L., 2004: Softening of wood polymers induced by moisture studied by dynamic FTIR spectroscopy. Journal of Applied Polymer Science, 94: 2032-2040. https://doi.org/10.1002/app.21133

2. Alen, R.; Kotilainen, R.; Zaman, A., 2002: Thermochemical behavior of Norway spruce (Picea abies) at $180-$ $225^{\circ} \mathrm{C}$. Wood Science and Technology, 3 (2): 163-171. https://doi.org/10.1007/s00226-001-0133-1

3. Candan, Z.; Korkut, S.; Unsal, O., 2013: Thermally compressed poplar wood (TCW): Physical and Mechanical Properties. Drvna industrija, 64 (2): 107-211. https://doi.org/10.5552/drind.2013.1216

4. Ebrahimi, E. A.; Sagheb Talebi, K. H.; Gorji Bahri, Y., 2004: Site demands of false walnut (Pterocarya fraxinifolia) in Vaz experimental forest of Mazandran province. Iranian Journal of Forest and Poplar, 12 (4): 481-507.

5. Edalat, H. R.; Tabarsa, T.; Reisi, M., 2008: Densification of Paullownia wood by using of hot-press. Iranian Journal of Wood and Paper Science Research, 23 (2): 136148.

6. Esteves, B.; Ribeiro, F.; Cruz-Lopes, L.; Domingos, J. F. I., 2017: Densification and heat treatment of maritime pine wood. Wood Research, 62 (3): 373-388.

7. Jiang, J.; Lu, J.; Huang, R.; Li, X., 2009: Effect of time and temperature on the viscoelastic properties off Chinese fir wood. Drying Technology, 27: 1229-1234. https://doi.org/10.1080/07373930903266726

8. Kutnar, A.; Kamke, F. A.; Sernek, M., 2009: Density Profile and Morphology of viscoelastic Thermal Compressed Wood. Wood Science and Technology, 43 (1-2): 57-68. https://doi.org/10.1007/s00226-008-0198-1
9. Madhoushi, M.; Grey, M.; Tabarsa, T; Rafighi, A., 2012: Nail and Screw Withdrawal Strength, MOE and MOR in Densified Poplar Wood. Journal of Wood and Forest Science and Technology, 18 (4): 45-58.

10. Tu, D.; Su, X.; Zhang, T.; Fan, W.; Zhou, Q., 2014: Thermo-mechanical densification of Populus tomentosa var. tomentosa with low moisture content. Bioresources, 9 (3): 3846-3856 https://doi.org/10.15376/biores.9.3.3846-3856

11. Sözbir, G. D.; Bektas I., 2017: The effect of heat Modification and densification on physical properties of poplar wood. Drvna industrija, 68 (4): 315-321. https://doi.org/10.5552/drind.2017.1719

12. Ülker, O.; Imirzi, O.; Burdurlu, E., 2012: The effect of densification temperature on some physical and mechanical properties of scots pine (Pinus sylvestris L.). BioResources, 7 (4): 5581-5592. https://doi.org/10.15376/biores.7.4.5581-5592

13. *** ISO 3131. 1975: Standard Test Method for Density of Regular Solids. International Organization for Standardization, Geneva, Switzerland.

14. *** ISO 3133. 1975: Wood- Determination of ultimate strength in static bending, International Organization for Standardization, Geneva, Switzerland.

15. *** British Standards Institution BS EN 1383:1999: Timber structures. Test methods. Pull-through resistance of timber fasteners.

\section{Corresponding address:}

Assoc. Prof. MAJID KIAEI, Ph.D.

Department of Wood and Paper Science

and Technology

Chaloos Branch, Islamic Azad University

Chaloos, IRAN

e-mail: Mjd_kia59@yahoo.com,Mjd-kia59@iauc.ac.ir 